DOI: $10.2478 / \mathrm{v} 10190-010-0006-2$

\title{
CHANGE IN N AND P CONCENTRATIONS \\ IN ANTARCTIC STREAMS AS A RESPONSE TO CHANGE IN PENGUIN POPULATIONS
}

\author{
ARKADIUSZ NĘDZAREK \\ Department of Hydrochemistry and Water Protection, Westpomeranian University \\ of Technology in Szczecin, K. Królewicza 4h, 71-550 Szczecin, Poland, \\ Department of Antarctic Biology, Polish Academy of Sciences, Ustrzycka 10/12, \\ 02-141 Warszawa, Poland \\ e-mail: arkadiusz.nedzarek@zut.edu.pl
}

\begin{abstract}
This study presents changes in the concentrations of nitrogen and phosphorus in two streams in Western Antarctica (Admiralty Bay, King George Island, South Shetlands) that differ in trophic status. The results suggest a decline in concentrations of the determined forms of $\mathrm{N}$ and $\mathrm{P}$ between 2001 and 2005. The decrease ranged from $9.3 \%$ for reactive phosphorus to $73.2 \%$ for ammonium-nitrogen. Such inferred declines in $\mathrm{N}$ and $\mathrm{P}$ concentrations are considered to reflect reduced deposition on land of organic matter brought in from the seas by the penguins nesting in the area. The ultimate cause of this is in turn the steady decline in abundance that is being noted for these penguins.
\end{abstract}

KEY WORDS: Antarctica, fresh water, nitrogen, prhosphorus, penguins population.

\section{INTRODUCTION}

The changes in trophic systems taking place in the Southern Ocean in the late $20^{\text {th }}$ and early $21^{\text {st }}$ centuries are being augmented currently by trophic changes in Antarctica's terrestrial ecosystem, both in their turn reflecting global warming (Everson 1977; Russell et al. 2006; Moline et al. 2004). Climatic warming has been demonstrated for the sub-Antarctic and the Antarctic Peninsula over 4 decades now 
(Martianov and Rakusa-Suszczewski 1990; King 1994; Skvarca et al. 1998; Cook et al. 2005; Turner et al. 2005; Turner et al. 2007; Stammerjohn et al. 2008), and the consequences have included ongoing deglaciation, and hence the appearance of new ice-free areas both along the coast and inland (Birkenmajer 2002).

The terrestrial ecosystem here is strongly interconnected with the marine ecosystem, thanks to a plethora of diverse ecological linkages. The feces organic matter originating in the sea is first and foremost brought in by birds and marine mammals that come to land to either breed or rest (Rakusa-Suszczewski 2003). In this way, ongoing changes (the aforementioned deglaciation plus changes in numbers of the birds and mammals referred to) feed back further through modifications in amounts of organic matter transferred to land. In the face of an ever-larger ice-free area on the one hand, and a decline in seabird populations on the other, it is possible to anticipate the dual effects of reduced transfers of organic matter to land. This organic matter is dispersal over an ever-wider area and dispersal of the organic matter could be a reason of a lowering of its concentrations in given places. Such relative impoverishment of land areas as regards biogenic elements is likely to slow the pace at which land newly exposed from under the ice is first colonized by plants and then undergoes succession. Furthermore, those terrestrial vegetation associations that have developed fully may now start to experience, or may already be experiencing, disrupted functioning.

The work detailed here has sought to consider the influence of changes in nesting populations of penguins on the trophic statuses of two different streams. Work done in 2001 and 2005 involved the mouth sections of the oligotrophic Petrified Forest Creek and the mezotrophic Ornithologists Creek, both located on the western shore of Admiralty Bay (King George Island, South Shetlands, West Antarctica). The results presented may also apply to other land areas of Antarctica subjected to similar changes.

\section{STUDY AREA}

Admiralty Bay falls within the sub-polar climatic zone, which is characterised by strong winds, high air humidity, precipitation totals exceeding $505 \mathrm{~mm}$, major weather changes over 24-hour periods and marked fluctuations in air temperature (from $-32^{\circ} \mathrm{C}$ to $+16^{\circ} \mathrm{C}$ ) (Kratke and Wielbińska 1981, Styszyńska 1990; Marsz and Styszyńska 2000).

The watercourses studied are on the western shore of Admiralty Bay (Fig. 1), and are known to differ from each other in trophic status and type of drainage basin. Petrified Forest Creek (length c. 1300m) is an oligotrophic stream whose catchment is of initial soils, with no colonies of penguins present. The birds nesting here are mainly brown skuas (Catharacta antarctica). In turn, Ornithologists Creek (length c. $1100 \mathrm{~m}$ ) is a mezotrophic stream flowing along most of its length through relict 
ornithogenic soils. This Creek's drainage basin includes colonies of adelie penguins (Pygoscelis adeliae) and gentoo penguins (Pygoscelis papua), as well as brown skuas (C. antarctica) and giant petrels (Macronectes giganteus).

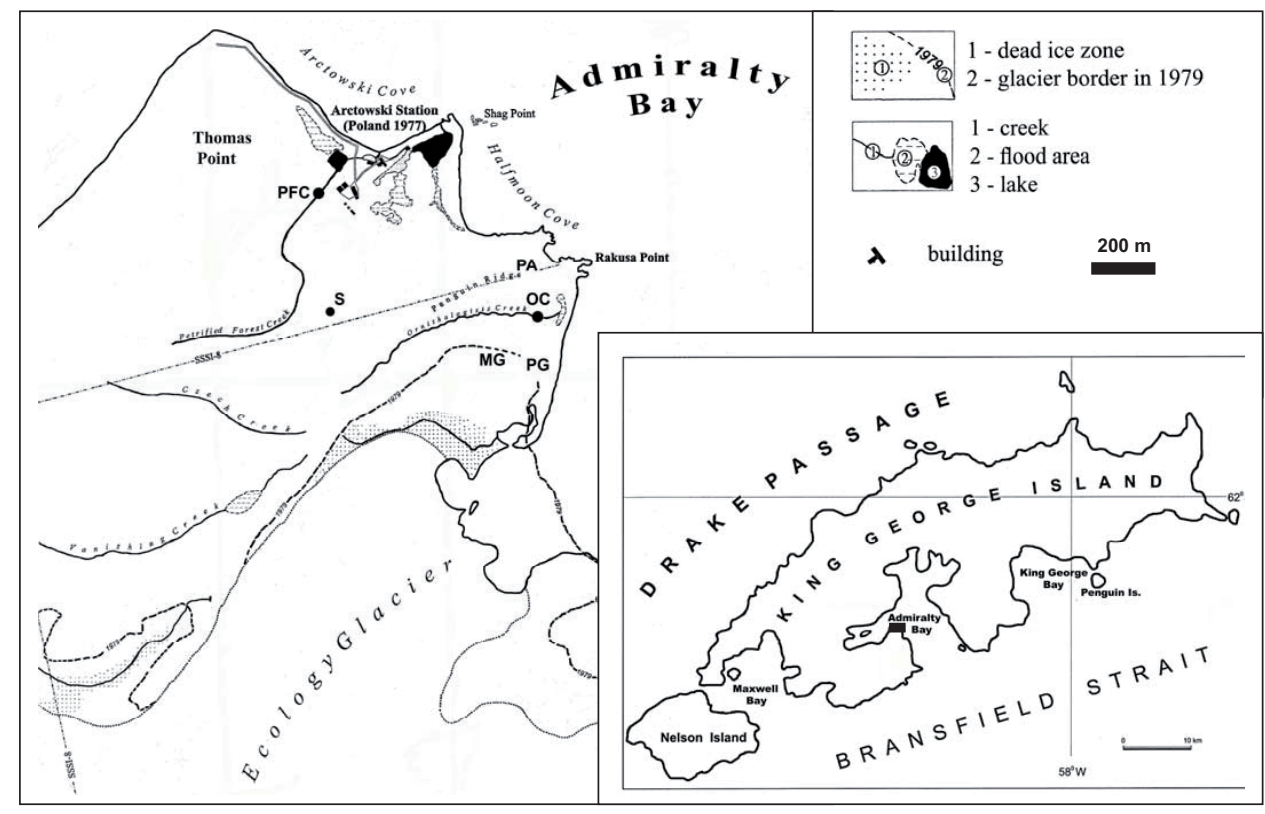

Figure 1. Locations of: water-sampling sites along Petrified Forest Creek (PFC) and Ornithologists Creek (OC), snow-sampling sites (S), and breeding colonies of: adelie penguins $P$. adeliae (PA), gentoo penguins $P$. gentoo (PG) and giant petrels $M$. giganteus $(\mathrm{MG})$

\section{MATERIAL AND METHODS}

Studies carried out in 2001 and 2005 concerned the waters of the mouth sections of Ornithologists Creek and Petrified Forest Creek (Fig. 1). Sampling in 2001 involved 9 samples taken in the January-May period and in November, while that done in 2005 comprised 4 samples taken between January and March inclusive. Then the samples were assayed for inorganic species of nitrogen (nitrite, nitrate, and ammonia nitrogen), total nitrogen (TN), reactive phosphorus (RP), and total phosphorus (TP) according to the standard colorimetric techniques recommended by APHA (1995), using a CARL ZEISS SPECOL-1100 spectrophotometer. Nitrite nitrogen was assayed with sulphanyl acid $(\lambda=543 \mathrm{~nm})$. Nitrate nitrogen was determined after reduction to nitrites on a $\mathrm{Cu}-\mathrm{Cd}$ column as nitrites. Ammonium nitrogen was assayed with indophenol blue $(\lambda=630 \mathrm{~nm})$. Total nitrogen was determined, as nitrates, after mineralisation with potassium hypersulphate. Organic nitrogen $(\mathrm{ON})$ content was calculated as the difference between total nitrogen and inorganic nitrogen (IN - sum of nitrite, nitrate, and ammonium nitrogen contents). 
Reactive phosphorus was assayed using the molybdenate technique with ascorbic acid as a reducer $(\lambda=882 \mathrm{~nm})$. Total phosphorus, after mineralisation with potassium hypersulphate, was assayed as reactive phosphorus. The difference between the two phosphorus species produced organic phosphorus (OP). Total dissolved solids (TDS) was measured with a WTW LF197 conductivity meter, pH with a HANNA HI 9025 pH-meter.

The resultant data were subjected to statistical treatment involving one-way analysis of variance (ANOVA) at $\mathrm{p}<0.05$, using the Statistica 7.1 software (StatSoft Inc. 2006).

\section{RESULTS}

The waters of Petrified Forest Creek were characterised by a neutral or slightly basic reaction, while those of Ornithologists Creek were slightly acid (the respective mean $\mathrm{pH}$ values for the two periods were 7.46 and 6.42). Salinities noted were higher in Ornithologists Creek and lower in Petrified Forest Creek, respective mean TDS values for the two research periods being 207.5 and $166.0 \mathrm{mg} \mathrm{dm}^{-3}$.

The scope of changes in the determined concentrations of forms of $\mathrm{N}$ and $\mathrm{P}$ was considerable, ranging from 0.050 to $4.042 \mathrm{mgN} \mathrm{dm}^{-3}$, in the case of inorganic nitrogen, for example, as well as from 0.004 to $0.829 \mathrm{mgP} \mathrm{dm}^{-3}$ in the case of reactive phosphorus (Tab. 1). Lower concentrations of $\mathrm{N}$ and $\mathrm{P}$ were noted in the waters of Petrified Forest Creek than in those of Ornithologists Creek, which in fact had more than 10 times as much nitrogen and around 15 times as much phosphorus. The main form of inorganic nitrogen was nitrate-nitrogen, with a particular distinct prevalence of this form over ammonium-nitrogen being noted for the waters of Ornithologists Creek, where it accounted for some $90 \%$ of inorganic nitrogen. In turn, the relevant share in the waters of Petrified Forest Creek was of c. 67\%. Inorganic nitrogen was the main (c. 69\%) component of total nitrogen in Ornithologists Creek, while the opposite situation applied in Petrified Forest Creek, where $60 \%$ of total $\mathrm{N}$ was in the form of organic nitrogen. In the case of reactive phosphorus, only slight differences in the share of total $\mathrm{P}$ this accounted for were noted. In Petrified Forest Creek, reactive $\mathrm{P}$ represented $52 \%$ of total $\mathrm{P}$, as compared with $60 \%$ in the case of Ornithologists Creek.

The comparison between the research periods revealed higher values for both $\mathrm{pH}$ and TDS in the two streams, when the 2005 samples were set against those collected and analysed back in 2001 (Tab. 2). Concentrations of nitrite- and nitrate-nitrogen were also higher in the waters of Ornithologists Creek (only) - respectively by $731.4 \%$ and $19.4 \%$ ). In the cases of the remaining indicators analysed, concentrations determined for 2005 samples were lower than had been noted in 2001. That dependences were usually statistically significant (ANOVA, $p<0.05-$ Fig. 2). In Petrified Forest Creek, concentrations of all analysed forms of nitrogen were lower 


\begin{tabular}{|c|c|c|c|c|c|c|c|c|c|}
\hline Z & \multirow{6}{*}{ 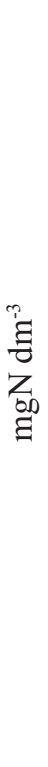 } & 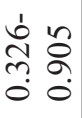 & $\frac{m}{0}$ & $\begin{array}{ll}1 & 8 \\
& 0 \\
0 & 0 \\
0 & 0\end{array}$ & ठै. & 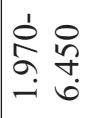 & 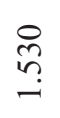 & 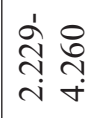 & ڤे \\
\hline za & & 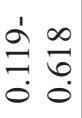 & $\frac{8}{3}$ & 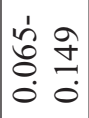 & ت্ & 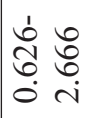 & $\begin{array}{l}\hat{\imath} \\
\hat{0}\end{array}$ & 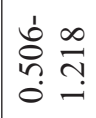 & $\begin{array}{l}\text { ô } \\
\text { ?n. } \\
0\end{array}$ \\
\hline Z & & 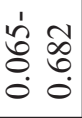 & 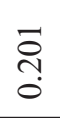 & $\mid \begin{array}{ll}1 & 0 \\
0 & 1 \\
0 & 1 \\
0 & 0 \\
0\end{array}$ & ֶิ & $\begin{array}{ll}\hat{1} & \mathfrak{2} \\
\hat{\sigma} & \hat{\sigma} \\
0 & \tilde{n}\end{array}$ & $\stackrel{8}{\circ}$ & 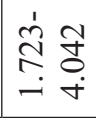 & $\begin{array}{l}\text { D. } \\
\infty \\
0 \\
0\end{array}$ \\
\hline $\begin{array}{l}Z_{z^{\prime}} \\
\mathbf{P}^{+} \\
\mathbf{z}^{+}\end{array}$ & & $\begin{array}{l}\frac{1}{5} \\
\vdots \\
0 \\
0\end{array}$ & : & $\mid \begin{array}{ll}1 & + \\
0 & 0 \\
0 & 0 \\
0 & 0\end{array}$ & ठे. & 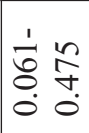 & $\frac{g}{\dot{O}}$ & $\begin{array}{ll}\dot{1} & \infty \\
0 & 0 \\
0 & = \\
0 & 0\end{array}$ & $\frac{\Delta}{\circ}$ \\
\hline $\begin{array}{l}z_{1} \\
0^{m} \\
Z\end{array}$ & & 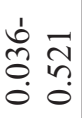 & $\frac{4}{6}$ & $\begin{array}{ll}1 & 0 \\
0 & 0 \\
0 & 0 \\
0 & 0\end{array}$ & $\begin{array}{l}\hat{\sigma} \\
\stackrel{0}{0}\end{array}$ & 它 & $\stackrel{0}{0}$ & $\stackrel{\dot{\vartheta}}{\stackrel{\leftrightarrow}{-} \bar{\sigma}}$ & 웅. \\
\hline $\begin{array}{l}z_{1} \\
0^{N} \\
z^{N}\end{array}$ & & $\begin{array}{ll}1 & n \\
\delta & 0 \\
0 & 0 \\
0 & 0 \\
0 & 0\end{array}$ & $\vec{\Xi}$ & $\mid \begin{array}{ll}1 & 0 \\
0 & 0 \\
0 & 0 \\
0 & 0\end{array}$ & $\begin{array}{l}n \\
0 \\
0\end{array}$ & 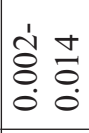 & $\begin{array}{l}\text { I } \\
8 \\
0\end{array}$ & 官交 & $\begin{array}{l}\stackrel{\partial}{\circ} \\
\stackrel{0}{0}\end{array}$ \\
\hline$\stackrel{R}{E}$ & \multirow{3}{*}{ 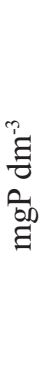 } & $\begin{array}{ll}1 & \infty \\
\bar{\delta} & 0 \\
0 & 0 \\
0 & 0\end{array}$ & $\stackrel{1}{0}$ & {$\left[\begin{array}{cc}1 & n \\
0 & 0 \\
0 & 0 \\
0 & 0\end{array}\right.$} & $\stackrel{\widetilde{\delta}}{0}$ & 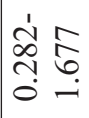 & $\frac{a}{n}$ & 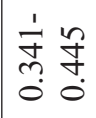 & $\stackrel{\infty}{0}$ \\
\hline ซิ & & 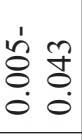 & $\stackrel{m}{0}$ & 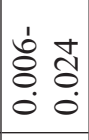 & $\stackrel{0}{0}$ & \begin{tabular}{ll}
1 & \multicolumn{1}{c}{} \\
0 & 0 \\
0 & 0 \\
0 & 0
\end{tabular} & 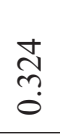 & 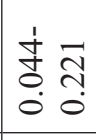 & ڤn \\
\hline$\approx$ & & 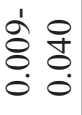 & $\vec{\sigma}$ & 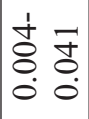 & $\stackrel{0}{0}$ & 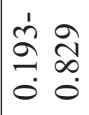 & $\frac{n}{\pi}$ & 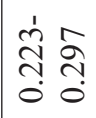 & $\begin{array}{l}\text { 웅. } \\
0\end{array}$ \\
\hline 气ิ & $\begin{array}{l}\tilde{\xi} \\
\xi \\
00 \\
\Xi\end{array}$ & 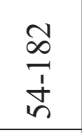 & $\ddot{m}$ & 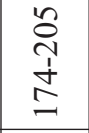 & 吉 & 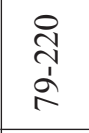 & $\underset{\dot{\sigma}}{\dot{t}}$ & 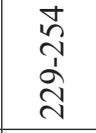 & $\stackrel{g}{=}$ \\
\hline 空 & & 它号 & ?ొ & $\begin{array}{cc}\dot{d} & 0 \\
\infty & 0 \\
\sim & \infty\end{array}$ & $\stackrel{8}{0}$ & $\begin{array}{ll}1 & n \\
n & n \\
n & 0\end{array}$ & ले & ồ & ¿.0. \\
\hline \multirow{3}{*}{ 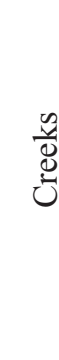 } & \multirow{3}{*}{ 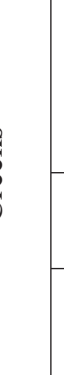 } & $\begin{array}{l}80 \\
: 00 \\
:\end{array}$ & 命 & 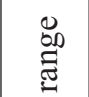 & 命 & 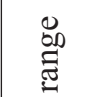 & 命 & 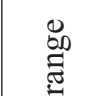 & 合 \\
\hline & & ठ্ণ & & 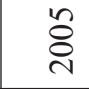 & & ఠ্ণ & & 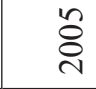 & \\
\hline & & \multicolumn{4}{|c|}{$\begin{array}{l}u \\
\text { L } \\
\text { L }\end{array}$} & \multicolumn{4}{|c|}{ ठ } \\
\hline
\end{tabular}


a)
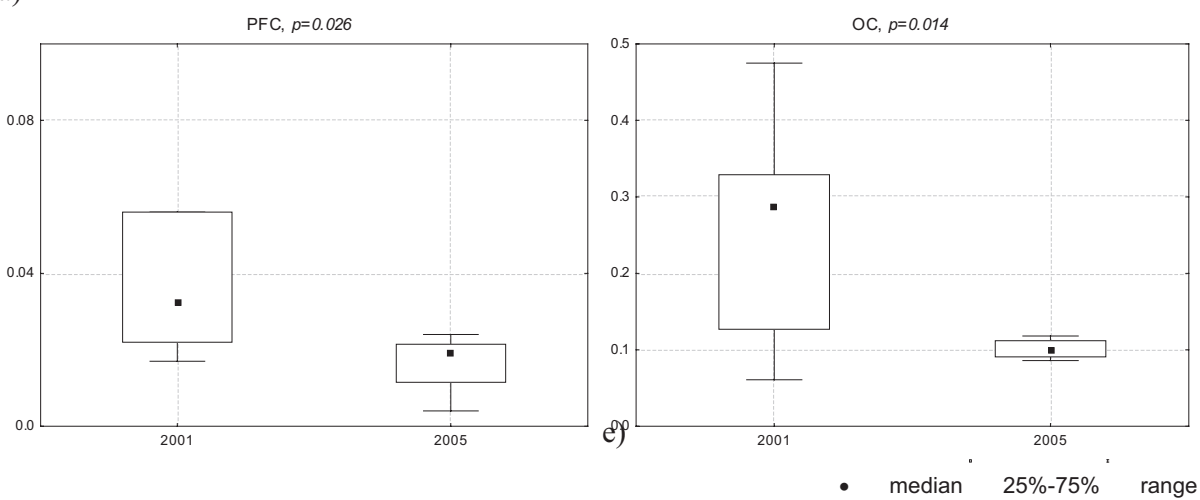

b)
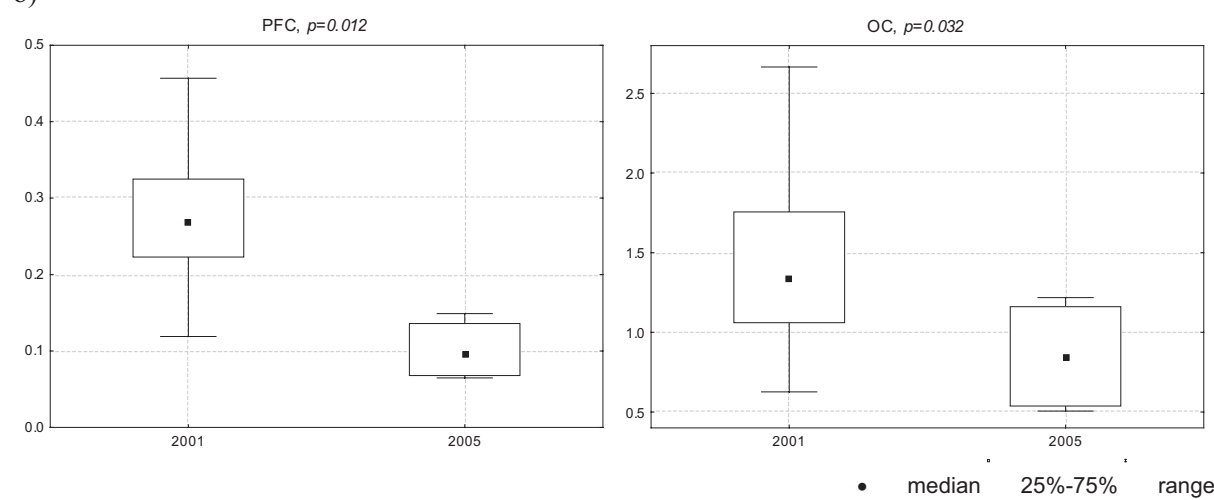

c)
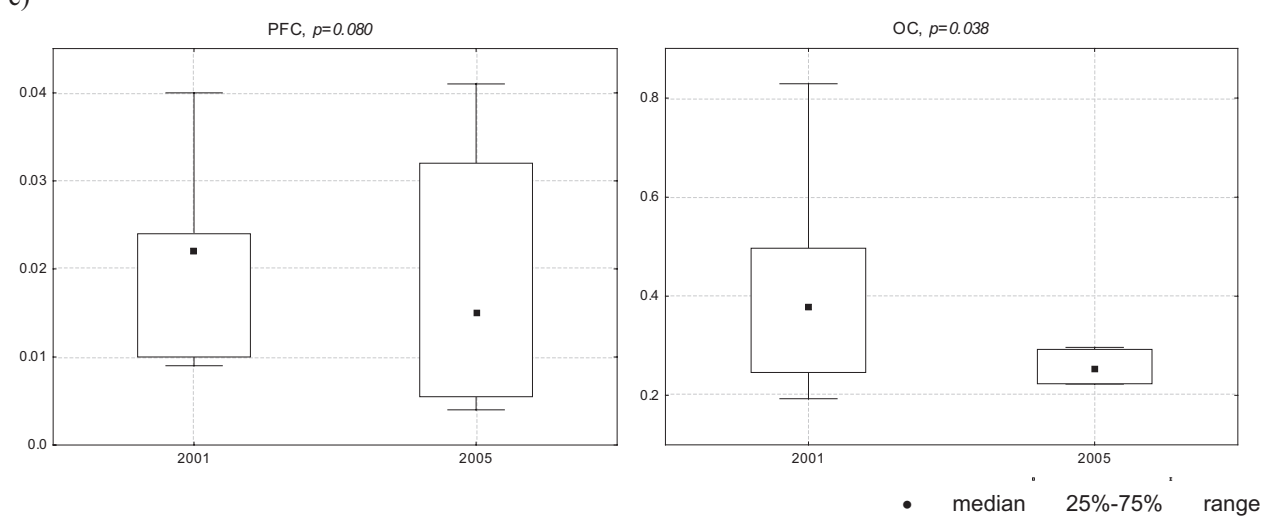
d)
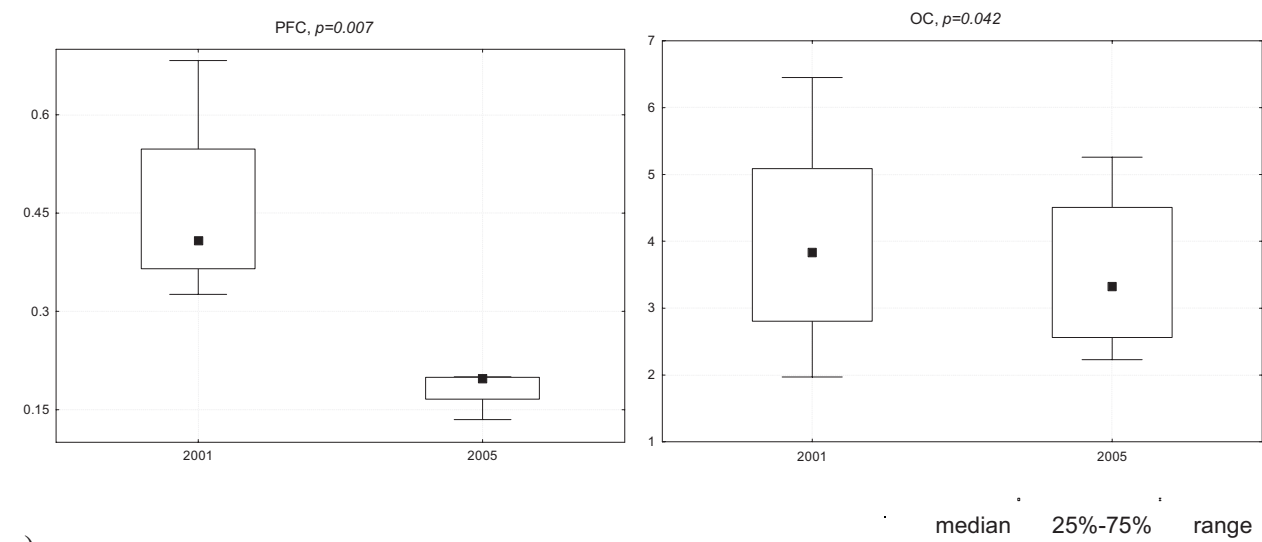

e)
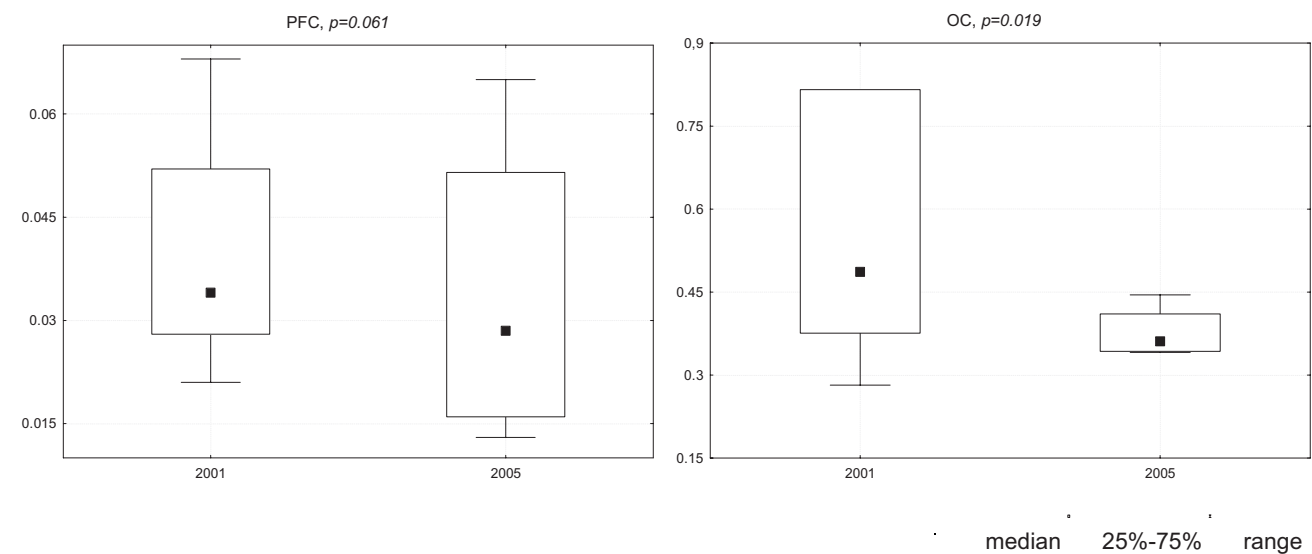

Figure 2. The differentiation of concentration: a) - ammonium-nitrogen; b) - organic nitrogen $(\mathrm{ON}) ; \mathrm{c})$ - reactive phosphorus $\left.\left(\mathrm{RP}, \mathrm{mgP} \mathrm{dm}^{-3}\right) ; \mathrm{d}\right)$ - total nitrogen $\left(\mathrm{TN}, \mathrm{mgN} \mathrm{dm}^{-3}\right)$; e) - total phosphorus (TP, $\mathrm{mgP} \mathrm{dm}{ }^{-3}$ ) at Petrified Forest Creek (PFC) and Ornithologists Creek (OC) in 2001-2005

The dependences statistically significant (ANOVA, $\mathrm{p}<0.05$ ).

- in some cases by more than $50 \%$ and in extremis by $73.2 \%$ (in the case of ammonium-nitrogen) (Tab. 2). In turn, the comparisons between the recent and earlier concentrations of phosphorus compounds suggested more limited change (these in no case being more than $25 \%$ lower).

In Ornithologists Creek, the concentration of total $\mathrm{N}$ was not more than $10 \%$ lower, while the concentration of ammonium-nitrogen was $60.5 \%$ lower. Compared with Petrified Forest Creek, Ornithologists Creek had waters in which concentrations of the determined forms of $\mathrm{P}$ were down by $39.2 \%$ in the case of reactive phosphorus, and $62.1 \%$ in the case of organic phosphorus (Tab. 2). 


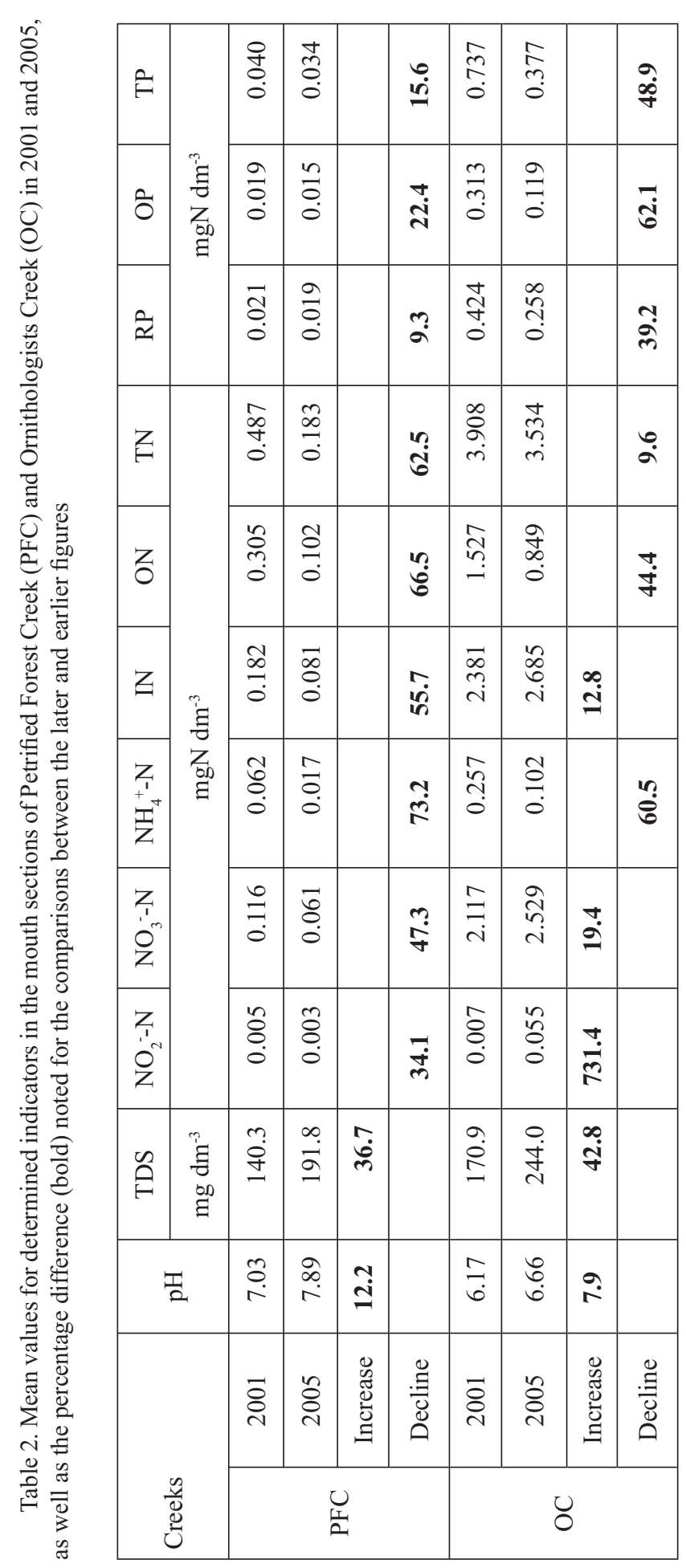




\section{DISCUSSION}

The values for the analysed hydrochemical indicators reported for the two streams were typical for fresh waters in the Antarctic close to the sea. Numerous other studies have yielded similar ranges of values (e.g. Howard-Williams et al. 1989, Vinocur and Unrein 2000, Elster and Komarek 2003 or Toro et al. 2007). Like those in other climatic zones, the lotic waters of Antarctica are open ecosystems whose primary production is conditioned by the influx of allochthonous matter. At the same time, and as numerous studies have made clear, primary production is relatively low at the lotic waters of Antarctica, even where waters are very rich in biogenic elements (Peterson et al. 1986; Vincent and Howard-Williams 1986; Howard-Williams et al. 1989; Elster and Komarek 2003).

The fact that $\mathrm{pH}$ values in Petrified Forest Creek were higher than previously may reflect the slightly greater productivity of the stream, as demonstrated by Elster and Komarek (2003). Thanks to the relatively weak buffering capacity of Antarctic streamwaters, even quite minimal changes in levels of primary production may give rise to marked changes in reaction (Toro et al. 2007). As Elster and Komarek (2003) suggested, the acid reaction demonstrated for Ornithologists Creek may reflect the decay of penguin guano in its catchment, as well as the influx of acidic waters infiltrating ornithogenic soils demonstrated by Juchnowicz-Bierbasz (1999) and Juchnowicz-Bierbasz and Rakusa-Suszczewski (2002).

Streamwaters in Antarctica are fed by melting glaciers and permafrost, as well as by melting snow, this fact accounting for their low salt content. Equally, however, it is typical for marine aerosols to raise salinity levels - in the coastal zone in particular (Caulkett and Ellis-Evans 1997; Toro et al. 2007). As Nędzarek and Rakusa-Suszczewski (2007) showed, average conductivity of rain on the least-elevated coastal terrace (at $2 \mathrm{~m}$ a.s.1.) was $1613 \mu \mathrm{S} / \mathrm{cm}$. The streams studied here had low salinities, the higher TDS concentration in Ornithologists Creek probably being shaped by the marine aerosol effect referred to.

The lakes and streams of Antarctica range in trophic status from the ultra-oligotrophic through to the hypertrophic, the conditioning factor here being the influx of biogenic elements from nutrients brought to land by seabirds and marine mammals (Vinocur and Unrein 2000; Rakusa-Suszczewski 2003).

The noted enriched trophic status of Ornithologists Creek is the known effect exerted by the very close proximity of seabird colonies, as well as the nature of the catchment, which has ornithogenic soils rich in nitrogen and phosphorus compounds. The waters infiltrating them are thus enriched in $\mathrm{N}$ and $\mathrm{P}$, there being particularly high concentrations of nitrate-nitrogen as a reflection of guano mineralisation and nitrification (Juchnowicz-Bierbasz 1999; Tatur 2002; JuchnowiczBierbasz and Rakusa-Suszczewski 2002). This stream thus shows a prevalence of non-autotrophic biological activity (Elster and Komarek 2003).

In contrast, Petrified Forest Creek is an autotrophic stream with low concentrations of biogenic elements, since its catchment lies beyond the area of direct impact 
of seabird colonies and is - therefore - built of N- and P-poor mineral soils at an early stage of development. The differences in primary production indicated by Elster and Komarek (2003) reflect the different proportions noted when it comes to the shares of different forms of inorganic and organic nitrogen comprising total N. In Petrified Forest Creek, organic nitrogen represents $60 \%$ of total nitrogen a typical ratio for waters in which autochthonous production prevails over allochthonous influxes of matter (Elster and Komarek 2003). A prevalence of the influx of allochthonous matter was in turn observed in Ornithologists Creek, in which 69\% of total $\mathrm{N}$ was accounted for by inorganic nitrogen.

In the case of the determined forms of phosphorus there is less sign than previously of differences in the percentage shares of total $\mathrm{P}$ accounted for by the mineral (reactive) form, the proportions being 52\% and 60\%. On account of its being able to bind permanently to alluvial material, phosphorus is a less labile element than nitrogen, and is only to a much lesser degree leached out of ornithogenic soils by percolating water. This is why $\mathrm{P}$ concentrations are lower than those of $\mathrm{N}$ even in streams that under major pressure from breeding colonies of seabirds or marine mammals (Tatur and Myrcha 1984; Juchnowicz-Bierbasz 1999).

If they represent a genuine downward trend (as seems likely), the lower concentrations of the different forms of $\mathrm{N}$ and $\mathrm{P}$ in the streams now, as opposed to before, are probably a reflection of declines in local penguin populations. Data presented by Angiel and Korczak (2008) show that the study area has probably experienced a $70+\%$ decline in the population of penguins over the last 3 decades (Tab. 3). Recent studies have found that many penguin populations in the Antarctic Peninsula have been in decline over the past 5-20 years (Woehler et al. 2001, Sander et al. 2007). This decrease in populations has stimulated several attempts to interpret these changes in relation to such diverse factors as human disturbance, climate change, and reduced food availability (Croxall et al. 2002, Weimerskirch et al. 2003, Lescroël and Bost 2006).

Tables 3. The number of breeding pairs of penguins on Admiralty Bay, King George Island in 1979-2006 (after Jabłoński 1984', Ciaputa and Sierakowski 1999², Angiel and Korczak 2008³)

\begin{tabular}{|l|c|c|c|c|c|}
\hline \multicolumn{1}{|c|}{ Penguins } & \multirow{2}{*}{$1979^{1}$} & \multirow{2}{*}{$1990^{2}$} & \multirow{2}{*}{$2006^{3}$} & \multicolumn{2}{|c|}{ Decline (\%)* } \\
\cline { 5 - 7 } & & & & $\mathrm{a}$ & $\mathrm{b}$ \\
\hline Pygoscelis papua & 3703 & 2401 & 3093 & 16.5 & - \\
\hline Pygoscelis adeliae & 32918 & 15609 & 7375 & 77.6 & 52.7 \\
\hline Pygoscelis antarctica & 5712 & 3026 & 1116 & 80.5 & 63.1 \\
\hline
\end{tabular}

*Percent (\%) decline describes the overall change in the number of breeding pairs between: a) 1979 and 2006; b) 1990 and 2006. 
In the same period, the study area has also been subject to ongoing deglaciation, the ice-free area on King George Island having increased from 21 to $38 \mathrm{~km}^{2}$ (Braun et al. 2001). In the 1970s, the mass of penguin guano deposited on land in the Admiralty Bay area was an estimated $230 \mathrm{t}$ a year (Rakusa-Suszczewski 2003). The more than $70 \%$ fall in the local population of penguins already alluded to (Tab. 3) can be assumed to have resulted in a decline in guano deposition to just $70 \mathrm{t}$ annually at present. This obviously suggests a major decline in the input of organic matter and biogenic elements into the ecosystem in question. It further needs to be stressed how the 70 tones of guano referred to are now the source of elements otherwise in short supply for a far larger ice-free area of land than there was previously. While the "main centres of nutrient inputs" constituted by the rookeries and their immediate surroundings (up to c. $400 \mathrm{~m}$ around colonies, according to the author's own unpublished data) continue to supply a considerable load of biogenic elements, the areas inland of them are presumably obtaining ever more limited enrichment in $\mathrm{N}$ and $\mathrm{P}$. This reflects the role of precipitation as the main agent transporting these elements inland (Nędzarek and Rakusa-Suszczewski 2007). As is made clear by presentations of determined $\mathrm{N}$ and $\mathrm{P}$ concentrations in snow sampled in 2001 and 2005 some $400 \mathrm{~m}$ from the centre of the breeding colony (Tab. 4), a downward trend for concentrations of biogenic elements in precipitation is to be anticipated. While the snow-sampling site is really not far from the breeding colony, concentrations of $\mathrm{N}$ and $\mathrm{P}$ are quite markedly lowered there - by as much as $80 \%$ in the case of phosphorus. One implication of this may be the observed fact that $\mathrm{N}$ and $\mathrm{P}$ concentrations in the watercourses studied (Petrified Forest Creek in particular) are now considerably lower than they were.

Table 4. Differences in $\mathrm{N}$ and $\mathrm{P}$ concentrations in snow fall sampled $400 \mathrm{~m}$ from the penguin colony in 2001 and 2005

\begin{tabular}{|c|c|c|c|c|c|}
\hline \multirow{2}{*}{ Years } & $\mathrm{NO}_{3}^{-}-\mathrm{N}$ & $\mathrm{NH}_{4}^{+}-\mathrm{N}$ & $\mathrm{TN}$ & $\mathrm{TRP}$ & $\mathrm{TP}$ \\
\cline { 2 - 6 } & \multicolumn{3}{|c|}{$\mathrm{mgN} \mathrm{dm}^{-3}$} & \multicolumn{2}{|c|}{$\mathrm{mgP} \mathrm{dm}{ }^{-3}$} \\
\hline 2001 & 0.020 & 0.056 & 0.349 & 0.020 & 0.040 \\
\hline 2005 & 0.019 & 0.042 & 0.287 & 0.004 & 0.008 \\
\hline Decline (\%) & 5 & 25 & 17.8 & 80 & 80 \\
\hline
\end{tabular}

If the inputs of $\mathrm{N}$ and $\mathrm{P}$ into the study area's initial soils have declined as much as the figures suggest, the consequences may be negative, not only for newly icefree areas of land - whose steady colonization by vegetation has been observable up to now, but also for areas that had become distinctly nutrient-rich previously, but may now be undergoing a nutrient impoverishment that may ultimately convert them into nutrient-poor ecosystems of the typical Antarctic tundra kind. 


\section{REFERENCES:}

Angiel P., Korczak M., 2008, Comparison of population size of penguins concerning present and archive data from ASPA 128 and ASPA 151 (King George Island), Scientific Committee on Antarctic Research (SCAR), International Arctic Science Committee (IASC), Polar Research - Arctic and Antarctic Perspectives in the International Polar Year. SCAR/IASC IPY. Open Science Conference. St. Petersburg, Russia. July 8-11 ${ }^{\text {th }}$ 2008, Abstract volume, 241.

APHA, 1995, Standard Methods for Examination of Water and Wastewater, $19^{\text {th }}$ ed., Washington, DC, American Public Health Association, 1200 pp.

Birkenamajer K., 2002, Retreat of Ecology Glacier, Admiralty Bay, King George Island (South Shetlands, West Antarctica, 1956-2001, Bulletin of Polish Academy of Science, Earth Science, 50 (1), 15-29.

Braun M., Simoes J.C., Vogt S., Bremer U.F., Blindow N., Pfender M., Saurer H., Aquino F.E., Ferron F.A., 2001, An improved topographic database for King George Island: compilation, application and outlook, Antarctic Science, 13, 41-52.

Caulkett A.P., Ellis-Evans J.C., 1997, Chemistry of streams of Signy Island, maritime Antarctic: sources of major ions, Antarctic Science, 9, 3-11.

Ciaputa P., Sierakowski K., 1999, Long-term population changes of Adeliae, chinstrap and gentoo penguins in the regions of SSSI No8 and SSSI No 34, King George Island, Antarctica, Polish Polar Research, 20, 355-365.

Cook A.J., Fox A.J., Vaughan D.G., Ferrigno J.G., 2005, Retreating glacier fronts on the Antarctic Peninsula over the past half-century, Science, 308, 541-544.

Croxall J.P., Trathan P.N., Murphy E.J., 2002, Environmental change and Antarctic seabird population, Polar Science, 279, 1510-1514.

Elster J., Komarek O., 2003, Ecology of periphyton in a meltwater stream ecosystem in the maritime Antarctica, Antarctic Science, 15, 189-201.

Everson I., 1977, The Southern Ocean, the living resources of the Southern Ocean, FAO UNDP, Rome, 1-156.

Howard-Williams C., Priscu J.C., Vincent W.F., 1989, Nitrogen dynamics in two Antarctic streams, Hydrobiologia, 178, 51-61.

Jabłoński B., 1984, Distribution, number and breeding preference of penguins in the region of the Admiralty Bay (King George Island, South Shetlands Islands, Antarctica) in the season 1979/1980, Polish Polar Research, 5, 5-16.

Juchnowicz-Bierbasz M., 1999, Year-round changes of nutrients in fresh water bodies near Arctowski Station (South Shetland Islands, Antarctica), Polish Polar Research, 20, 243-258.

Juchnowicz-Bierbasz M., Rakusa-Suszczewski S., 2002, Nutrients and cations content in soil solutions from the present and relict penguin colonies (Admiralty Bay, King George Island), Polish Journal of Ecology, 50, 79-91.

King J.C., 1994, Recent climate variability in the vicinity of the Antarctic Peninsula, International Journal of Climatology, 14, 357-369.

Kratke J., Wielbińska D., 1981, Co-occurrence of particular meteorological elements in the region of Arctowski Station (King George Island, South Shetlands) in 1987, Polish Polar Research, 2 (3-4), 7-21. 
Lescroël A., Bost C.A., 2006, Recent decrease in gentoo penguin populations at Iles Kerguelen, Antarctic Science, 18, 171-174.

Marsz A.A., Styszyńska A., 2000, Główne cechy klimatu rejonu polskiej stacji antarktycznej im. H. Arctowskiego Antarktyka Zachodnia, Szetlandy poludniowe, wyspa Króla Jerzego (Main climate features of the area of H. Arctowski Antarctic Station West Antarctica, South Shetlands, King George Island), WSM Gdynia, 264pp. (in Polish)

Martianov V., Rakusa-Suszczewski S., 1990, Ten years of climate observations at the Arctowski and Bellingshausen Stations (King George Is., South Shetlands, Antarctica). [in]: Breymeyer A. (ed.), Global change regional research centres, Seminar paper and IGBP WG 2 report. Inst. Geogr. Spatial Organ. PAS, 80-87.

Moline M.A., Claustre H., Frazer T.K., Schofield O., Vernet M., 2004, Alternation of the food web along the Antarctic Peninsula in response to a regional warming trend, Global Change Biology, 10, 12, 1973-1980.

Nędzarek A., Rakusa-Suszczewski S., 2007, Nutrients and conductivity in precipitation in the coast of King George Island (Antarctica) in relation to wind speed and penguin colony distance, Polish Journal of Ecology, 55, 705-716.

Petereson B.J., Hobbie J.E., Corlins T.L., 1986, Carbon flow in a tundra stream ecosystem, Canadian Journal Fisheries Aquatic Science, 43, 1259-1269.

Rakusa-Suszczewski S., 2003, Functioning of the geoecosystem for the west side of Admiralty Bay (King George Island, Antarctica): outline of research at Arctowski Station, Ocean and Polar Research, 25 (4), 653-662.

Russell J.L., Dixon K.W., Gnanadesikan A., Stouffer R.J., Toggweiler J.R., 2006, The Southern Hemisphere Westerlies in a Warming World: Propping Open the Door to the Deep Ocean, Journal of Climate, 19, 6382-6390.

Sander M., Balbăo T.C., Polito, M.J., Costa, E.S., Corneiro A.P.B., 2007, Recent decrease in chinstrap penguin (Pygoscelis Antarctica) population at two of Admiralty Bay's islets on Kig George Island, South Shetlands, Antarctica, Polar Biology, 30, 659-661.

Skvarca P., Rack W.M., Rott H., Ibarzabal H., Donangel T., 1998, Evidence of recent climate warming on the eastern Antarctic Peninsula, Annals of Glaciology, 27, 628-632.

Stammerjohn S.E., Martinson D.G., Iannuzzi R.A., 2008, Sea ice in the western Antarctic Peninsula region: Spatio-temporal variability from ecological and climate change perspectives, Deep-Sea Research II 55, 2041-2058.

StatSoft Inc., 2006, Statistica (data analysis software system), version 7.1. www.statsoft. com.

Styszyńska A., 1990, The effect of wind direction and orography on air temperature at the Arctowski Station, Polish Polar Research, 11 (1-2), 69-93.

Tatur A., 2002, Ornithogenic Ecosystems in the Maritime Antarctic - Formation, Development and Disintegration, [in:] Beyer L., Bölter M. (eds), Geoecology of Antarctic Ice-Free Coastal Landscapes, Springer-Verlag Berlin Heidelberd, 161-184.

Tatur A., Myrcha A., 1984, Ornithogenic soils on King George Island, South Shetland Islands (Maritime Antarctic Zone), Polish Polar Research, 5 (1-2), 31-60.

Toro M., Camacho A., Rochera C., Rico E., Bańón M., Fernández-Valiente E., Marco E., Justel A., Avendańo M.C., Ariosa Y., Vincent W. F., Quesada A., 2007, Limnological characteristics of the freshwater ecosystems of Bayers Peninsula, Livingston Island, in maritime Antarctica, Polar Biology, 30, 635-649. 
Turner J., Colwell S.R., Marshall G.J., Lachlan-Cope T.A., Carleton A.M., Jones P.D., Lagun V., Reid P.A., Iagovkina S., 2005, Antarctic climate change during the last 50 years, International Journal of Climatology, 25 (3), 279-294.

Turner J., Overland J.E., Walsh J.E., 2007, An Arctic and Antarctic perspective on recent climate change, International Journal of Climatology, 27, 277-293.

Vincent W.F., Howard-Williams C., 1986, Antarctic stream ecosystem: physiological ecology of blue-green algal epilithon, Freshwater Biology, 16, 219-233.

Vinocur A., Unrein F., 2000, Typology of lentic water bodies at Potter Peninsula (King George Island, Antarctica) based on physical-chemical characteristics and phytoplankton communities, Polar Biology, 23, 858-870.

Weimerskirch H., Inchaust P., Guinet C., Barbraud C., 2003, Trends in bird and seal populations as indicators of system shift in the Southern Ocean, Antarctic Science, 15, 249-256.

Woehler E.J., Cooper J., Croxall J.P., Fraser W.R., Kooyman G.L., Miller G.D., Nel D.C., Tatterson D.L., Peter H.U., Ribic C.A., Salwicka K., Trivelpiece W.Z., Weimerskirch H., 2001, A statistical assessment of the status and trends of Antarctic and sub-Antarctic seabirds, Report on SCAR BBS workshop on Southern Ocean seabird populations. SCAR, Montana, 45 pp. 